\title{
Guardians of Workers' Bodies? Trade Unions and the History of Occupational Health and Safety
}

\section{Arthur McIvor}

\section{Labour History, 119, November 2020, pp. 1-30 (ISBN 978-1-80085-981-4)}

\section{Running head: McIvor • Trade Unions \& OHS}

\section{Note: There are several images to be included in this article}

Critically assessing the role and influence of trade unions on occupational health and safety (OHS), and tracing their contribution to OHS discourse is here examined through the lens of history in Britain positioned relative to international experience. The idea of trade union neglect of OHS is challenged through study of the historic role of trade unions and the more recent experience (since the 1970s) of unions' growing interest in OHS whilst simultaneously experiencing a sharp decline in membership and the adverse impact of this disempowerment on OHS standards. Acknowledging the politics of gender shows British unions neglected occupational health and embodiment issues that impacted upon women as workers. Robust and compelling evidence from the mid-twentieth century - that unions were a powerful countervailing force to workplace dangers, as key sentinels shielding workers' bodies - is followed by evidence of increasing occupational illnesses in the period of union decline and precarious work from c1980. The paper urges more critical reflection on trade unions as actors and as a voice in the OHS discourse.

Keywords: Trade Unions; Occupational Health; Safety; Industrialisation; Deindustrialisation; Workers' Bodies

Occupational health and safety comprises two separate though related areas. There are the acute issues around safety and danger, often referred to as "accidents." These traumas are usually sudden, immediate and visible - as with coal mining disasters. Then there are the occupational diseases linked to exposure to toxic and carcinogenic substances (such as asbestos), including dust inhalation, and to fatigue, stress and mental health issues. Whilst in the discussion that follows OHS will sometimes be conflated, this distinction is important to bear in mind as it does shape the historical responses of trade unions to the impact of work on bodies. The OHS literature has shown how medical recognition of occupational disorders, and the regulation of occupational health and safety, has in the past been the product of a complex interplay of actors and forces; the state, economy and politics, medical knowledge, public opinion, employers and management, workers and their trade unions. ${ }^{1}$ This was an intensely contested terrain between capital and labour in which workers and their agents played a key part. The paper is framed within the approach of social scientists, Quinlan, Bohle and Lamm, drawing inspiration from and building upon their ground-breaking work on experience in Australia. ${ }^{2}$ They argue that the unions were one of a series of players responsible for developing the OHS discourse from the nineteenth century, with varying degrees of influence. They posit a typology for trade union activity, with the identification of seven primary ways that trade unions protected workers' bodies:

1. Through negotiation or bargaining "with employers to eliminate OHS risks"

2. By providing "OHS information and logistical assistance to workers"

1. Alan Dembe, Occupation and Disease: How Social Factors Affect the Conception of Work-Related Disorders (New Haven, Conn.: Yale University Press, 1996); and see the historiography section of Arthur McIvor and Ronald Johnston, Miners' Lung: A History of Dust Disease in British Coal Mining (Aldershot: Ashgate, 2007), 14-23.

2. Michael Quinlan, Philip Bohle and Felicity Lamm, Managing Occupational Health and Safety: A Multidisciplinary Approach, 3rd ed. (South Yarra, Vic.: Palgrave Macmillan, 2010). 
3. Conducting "OHS education and training programs to workers, job delegates, etc."

4. Protecting "workers active on OHS issues from victimisation"

5. Campaigning "for improvements in OHS standards and legislation"

6. Playing a role in administering and "enforcement of OHS legislation"

7. Providing "advice and legal or other assistance to injured workers in terms of workers compensation campaigns, rehabilitation and common law actions for damages." 3

The task here is to show how the Quinlan, Bohle and Lamm typology maps on to the history of trade union involvement in OHS in Britain. There are three main themes to this literature.

\section{Trade Union Powerlessness and Neglect of the Body at Work}

For much of the nineteenth century, British employers regarded the organisation of work as their sole prerogative. Apart from some notable exceptions, trade unions lacked the power and presence to have much if any significant impact on OHS. The main drivers of reforms of the first half of the nineteenth century - like the Factory Act (1833) and Mines Act (1842) - therefore were not the unions but social reformers, medical/health research and public opinion, influenced by media exposes of disasters and accidents. ${ }^{4}$ At the end of the nineteenth century, still only around one in ten British workers were members of trade unions. ${ }^{5}$ Hence union activity in this era was frequently located within and a part of progressive alliances such as the anti-sweating leagues of the 1880s and 1890s working with the support of sympathetic social reformers, politicians, factory and mines inspectors, doctors, physicians, and religious groups. ${ }^{6}$

Quinlan, Bohle and Lamm also talk of "the priorities and strategic preferences of unions"7 which has resonance in the UK in relation to OHS. Some historians have argued that historically trade unions neglected occupational health and safety - or at least they prioritised wages, job security and compensation over protecting workers' bodies. ${ }^{8}$ The Friendly Society "insurance" functions of many craft and mining unions in the nineteenth century provided some financial cover if a worker was disabled by an injury on the job, or otherwise incapacitated. By not prioritising prevention or providing an effective counterweight to the forces of capital, these historians argue, corporate exploitation and crime were enabled to persist. So much more could have been done, earlier and more aggressively by the unions had they chosen to do so. Health historian Paul Weindling declared that "trade unions have often made pay a priority, and neglected health issues." "In a study in 1960, John Williams criticised the trade unions in Britain for lacking a clear accident prevention policy, declaring: "Within what limits can the community tolerate the introduction of safety standards by negotiation in slow motion." 10 Whilst noting the importance of trade union activities on compensation, the Factory and Mines Acts in the twentieth century and the campaign to get joint safety committees, Williams criticised what he saw as "a narrow approach" which did not focus on prevention. ${ }^{11}$ Graham Wilson also asserted in 1985: "Health and safety at work have mattered comparatively little to unions in Britain, as in the USA ... Only a minority of union officers and officials have shown passionate concern for safety and health at work." ${ }^{12}$ Other studies developed this theme of union failure in relation to workers' bodies. William Kenefick has argued that before World War II, Glasgow (Scotland) dockers were more likely to strike for a wage premium ("dirty"

3. Ibid., 485.

4. Ibid., 323.

5. Arthur McIvor, A History of Work in Britain, 1880-1950 (Basingstoke: Palgrave, 2001), 201.

6. Quinlan, Bohle and Lamm, Managing Occupational Health and Safety, 486.

7. Ibid.

8. See Phil B. Beaumont, Safety at Work and the Unions (Beckenham: Croom Helm, 1983), 42; Mass Observation, People in Production (Harmondsworth: Penguin, 1942), 203.

9. Paul Weindling, "Linking Self-Help and Medical Science," in The Social History of Occupational Health, ed. P. Weindling (London: Croom Helm, 1985), 10.

10. John L. Williams, Accidents and Ill Health at Work (London: Staples Press, 1960), 341.

11. Ibid., 343-44.

12. Graham Wilson, The Politics of Safety and Health (Oxford: Oxford University Press, 1985), 114. 
or "danger" money) than to down tools refusing to handle toxic products. He argued: "for the dockers, trade unionism was more closely linked to gaining preference in employment, and to protecting jobs from outsiders, than concerns over safety." 13

There are also fragments of oral evidence that corroborate such a negative view of trade union inaction. For example, a Scottish occupational health consultant Robin Howie commented in 2001:

There are unions which are the exception to the rule, but in my own experience trade unions have not been as concerned about things like health and safety as they are about the fact the job is still there and what the wage rates are ... the unions should have been going for better conditions ... for better safety in the workplace and they chose not to. ${ }^{14}$

Similarly, Scottish coal miner Alec Mills declared in an interview in June 2000: "Angry. Angry ... We never went on strike for masks. But we should have went on strike for masks. A lot of men would be alive today if they had been provided with masks." ${ }^{15}$ Mills is referring to the lack of personal protection equipment amid the epidemic of dust-related respiratory disease and disability that decimated coal mining communities in the UK. Following a court ruling in 1998 and the prescription of bronchitis and emphysema as occupational diseases for miners, over half a million claims were made for compensation for varying degrees of disability. ${ }^{16}$ The president of the National Union of Mineworkers (NUM) - Nicky Wilson - lamented that whilst the miners' unions had played a key role relating to safety and physical ill-health, historically they had neglected the psychological impacts of injury, death and disability which he equated with forms of post-traumatic stress disorder. ${ }^{17}$

One area where the case for trade union failure has been made extensively has been in relation to asbestos - amongst the most deadly of all occupational health epidemics in the twentieth and early twenty-first centuries. Environmental health activist Alan Dalton was particularly scathing about the role of the trade unions. In his book published in 1979 Dalton claimed that, right up to the mid-1970s, the trade unions were unable to provide significant information to the government on the incidence of the diseases associated with asbestos. This was compared to extensive union medical records in the USA, used to such good effect by the epidemiologist Irvine Selikoff. ${ }^{18}$ Dalton also argued that the unions prioritised compensation struggles over prevention. Dangers were accepted and extra wage payments negotiated by some unions. Such "danger money" deals were struck by many unions with employers and employers' associations, thus effectively condoning "murder" on the job. ${ }^{19}$ Furthermore, Dalton claimed, where there were individual rank-and-file activists trying to do something they were invariably opposed and sometimes even obstructed by the union hierarchy. ${ }^{20}$

Dalton's negative view of the trade union hierarchy on asbestos has largely been confirmed by subsequent academic research. Geoffrey Tweedale's brilliant expose of the corporate negligence of the premier British asbestos multi-national company Turner and Newall (using their own internal documents) depicts the trade unions as virtually invisible and having failed as a countervailing force. Hence, he asserts as regards asbestos: "trade unions had little impact before the 1970s." ${ }^{21}$ Nick Wikeley working through Trades Union Congress (TUC) papers argued in a similar vein that UK unions played

13. William Kenefick, Rebellious and Contrary: The Glasgow Dockers, 1853-1932 (East Linton: Tuckwell Press, 2000), 150-51.

14. Robin Howie, interviewed by Neil Rafeek, 20 September 2001, 017/C45, Scottish Oral History Centre Archive (hereafter SOHCA), University of Strathclyde.

15. Alec Mills, interviewed by Arthur McIvor, 19 June 2000, 017/C1, SOHCA.

16. See McIvor and Johnston, Miners' Lung, 180-81.

17. Nicky Wilson interview at the Mining Disability Witness Seminar, University of Strathclyde, 28 April 2014 , SOHCA.

18. Alan Dalton, Asbestos Killer Dust (London: BSSRS Publications, 1979), 79-80.

19. Ibid., 85 .

20. Ibid., 86 .

21. Geoff Tweedale, Magic Mineral to Killer Dust: Turner and Newall and the Asbestos Hazard (Oxford: Oxford University Press, 2000), 169. 
no significant role in shaping the pioneering Asbestos Industry (Asbestosis) Scheme 1931, nor in reforming and widening the coverage of such legislation up to the $1970 \mathrm{~s}^{22}$

Implicated in this alleged negligence were the peak organisations at the head of the union movement in Britain - the TUC and the Scottish Trades Union Congress (STUC). Robert Murray (TUC Medical Adviser, 1962-74) had impeccable prior credentials as an International Labour Organisation (ILO) expert and UK Medical Inspector of Factories. However, he was at best extremely conservative in his views on asbestos in the 1960s and early 1970s. In 1967, he undermined the position of striking London dockers by reporting "no unacceptable risk at present exists," and subsequently supported the building of a new asbestos factory in Ireland and compromised the position of unions in the USA on the occupational cancer risk. ${ }^{23} \mathrm{He}$ went on to defend the use of asbestos, to argue that it was a waste of taxpayers' money to strip asbestos from buildings and schools and to act as a supportive witness for the UK asbestos multinational Turner and Newall. ${ }^{24}$ His views influenced trade union policy in the UK in a critical period when the hazards of asbestos were becoming more widely known. Under his watch the unions continued to fail to initiate a comprehensive medical study of asbestos related disease. In Scotland the unions largely mirrored this neglect of asbestos as an OHS issue until the 1970s. ${ }^{25}$

A persuasive critique of the record of trade unions on OHS has also been articulated by feminist historians and commentators. As Karen Messing has eloquently argued, work and OHS are deeply gendered. The sorts of hazards and problems women have faced in the workplace have been neglected. ${ }^{26}$ "People," Messing has asserted, "just do not think of women's jobs in connection with occupational health." ${ }^{27}$ She also notes that the data under-represents accidents, injury and mortality of female workers as these were rarely included in workmen's compensation claims. ${ }^{28}$ Whilst science is the main culprit in Messing's thesis, trade unions might also be regarded as somewhat culpable. Unions tended to reflect the prevailing ideologies of gender difference and inequality, supporting, in the nineteenth century, the Factory Acts, Mines Acts and other legislation that excluded and subordinated women workers. ${ }^{29}$ Claire Williams has noted about Australia and New Zealand, "the Factories legislation and the labour movement has privileged the families of working-class men at the expense of working women, and particularly women providers with dependents, and often sick husbands." 30

Implicit and at times explicit gender segregation was premised on acceptance by the unions of the prevailing discourse of masculinity and femininity - ideas around who should legitimately be in fulltime paid employment (male workers as breadwinners) and who should be homemakers (married women). What was created was a "dangerous work taboo" whereby women were largely excluded from the most visible areas of work deemed to affect adversely their functions as mothers (or potential mothers), such as underground mining, construction, night work or working with lead. ${ }^{31}$ Whilst ostensibly protecting women from risk and harm, this practice ghettoised working women into other more precarious paid work, such as domestic service, clothing sweatshops, low-paid homework and monotonous machine-minding (as in textile factories) and assembly line work. Such work had less

22. Nick Wikeley, "Asbestos and Cancer: An Early Warning to the British TUC," American Journal of Industrial Medicine, no. 22 (1992): 449-54.

23. Dalton, Asbestos Killer Dust, 90-91.

24. Tweedale, Magic Mineral, 248-49; Dalton, Asbestos Killer Dust, 90-91.

25. For a wider discussion, see Ronald Johnston and Arthur McIvor, Lethal Work (East Linton, Scotland: Tuckwell Press, 2000), 30-62.

26. Karen Messing, One-Eyed Science: Occupational Health and Women Workers (Philadelphia: Temple University Press, 1998), xviii.

27. Ibid., 12

28. Ibid., 13-15.

29. For a UK perspective on this, see Sylvia Walby, Patriarchy at Work: Patriarchal and Capitalist Relations in Employment (Minneapolis: University of Minnesota Press, 1986); McIvor, A History of Work, 174-84.

30. Claire Williams, "Women and Occupational Health and Safety: From Narratives of Danger to Invisibility," Labour History, no. 73 (November 1997): 31.

31. The persistence of this "macho" dangerous work taboo is discussed in Ronnie Johnston and Arthur McIvor, "Dangerous Work, Hard Men and Broken Bodies: Masculinity in the Clydeside Heavy Industries," Labour History Review 69, no. 2 (August 2004): 135-53. 
exposure to acute accident risk, but more exposure to chronic long-term health problems that were less visible. ${ }^{32}$ Amongst the serious gender-related problems were repetitive strain injuries (RSIs) like telegraphist's cramp, musculo-skeletal problems like housemaid's knee, and fatigue. ${ }^{33}$ A clothing factory worker in Crewe, Ada Nield Chew, commented bitterly in 1894: "We cannot be said to live, we merely exist. We eat, we sleep, we work, endlessly work ... without remission ... Sunday is to many of us, after our week of slavery, a day of exhaustion." ${ }^{34}$ On top of this was the dual burden of paid work and unpaid domestic duties that women carried.

The male-dominated, and male-work oriented, British trade union movement largely neglected female-related OHS issues and not just through gender-exclusionary and discriminatory policies like failure to oppose the legal and societal marriage bar, or to promote equal pay. Unions also failed to recruit women pro-actively and they operated male-preference policies in relation to committee, executive and leadership positions. ${ }^{35}$ Women's voices were thus muted within the labour movement and they struggled to influence the prevailing OHS discourse. Consequently, the OHS problems and needs of women workers remained largely overlooked. Furthermore, denied access to apprenticeships in skilled and wellpaid rewarding work where men predominated, women were also denied the opportunity to enjoy enriching and dignified work that had positive implications for health and well-being.

The unions have thus been given a bad record on OHS matters. They have been regarded as having failed their members, by not devoting enough resources to prevention and campaigning on health; by discriminating against women workers; and by failing for a long period - at least up to the 1960s - to develop policies on OHS that specifically affected women workers, including the dual burden of unpaid domestic labour combined with paid work. To this we might add that the British trade unions failed to make full and effective use of the strike weapon (at least at industry and national level) that Quinlan, Bohle and Lamm's typology above (point 1) posits as a deterrent or as leverage to minimise the damage to workers' bodies. ${ }^{36}$

\section{Rehabilitating the Trade Unions and Occupational Health and Safety}

Recent research has led to some re-evaluation of the largely negative picture. The role of unions has been contextualised. The story has become more nuanced, with union interventions ranging widely across a spectrum, as Quinlan, Bohle and Lamm have postulated, and increasing in intensity and effectiveness over time, at least up to the heyday of trade unionism in the 1970s.

Campaigning on health and safety at work by unions was widespread and has long historical roots in some industries. The Fabian socialist writers Beatrice and Sidney Webb identified the unions in the cotton textile industry as amongst the most active after c1870 on OHS. ${ }^{37}$ The British cotton textile unions spearheaded several occupational health campaigns. ${ }^{38}$ Fatigue and overstrain, for example, lay behind concerted trade union attempts to control working hours. Cotton textile unions played a prominent part in the shorter working hours campaigns of the nineteenth and early twentieth centuries and women textile factory workers such as the weavers benefitted as well as the men. The work of Bowden and Tweedale on byssinosis ("brown lung") and very recently Greenlees on the clean air movement in USA and English textile factories, also show the contribution of textile trade unions in reforming the factory system. ${ }^{39}$ Other work has identified the agency of women workers, such as Bartrip's evaluation of the Women's Trade Union League which campaigned aggressively on lead poisoning from the 1880s to 1914, forcing

32. Williams, "Women and Occupational Health," 45.

33. Ibid., 46-48.

34. Cited in Doris Nield Chew, The Life and Writings of Ada Nield Chew (London: Virago, 1982), 75-76.

35. For a fuller discussion, see McIvor, A History of Work, 193-95.

36. Arthur McIvor, "Was Occupational Health and Safety a Strike Issue? Workers, Unions and the Body in Twentieth Century Scotland," Journal of Irish and Scottish Studies 8, no. 1 (2017): 5-33.

37. Sidney Webb and Beatrice Webb, Industrial Democracy (London: Longmans, 1897; 1902 ed.), 364.

38. Arthur McIvor, "Health and Safety in the Cotton Industry," Manchester Region History Review 9 (1995): $50-57$.

39. Sue Bowden and Geoff Tweedale, "Mondays without Dread: The Trade Union Response to Byssinosis in the Lancashire Cotton Industry in the Twentieth Century," Social History of Medicine 16, no. 1 (2003): 79-95; Janet Greenlees, When the Air Became Important (New Brunswick, NJ: Rutgers, 2019). 
reforms whilst retaining a commitment to a non-exclusionary employment strategy. ${ }^{40}$ This jarred, however, with the position adopted by the male-dominated trade union movement who remained largely committed to prioritising OHS issues that affected men. In the case of byssinosis, for example, the Cardroom Workers' Union endorsed the original compensation agreement that only applied to male and not female workers. ${ }^{41}$

Much depended on the power and strength of the trade unions at a local and national level. In the British coalfields miners organised powerful local and regional unions in the second half of the nineteenth century and these became amalgamated into an effective force with the formation of the Miners' Federation of Great Britain (MFGB) in 1888. In the early 1890s around 60 per cent of all coal miners (and there were around a million) were trade union members, rising in 1920 to around 90 per cent, making it by far the largest of all Britain's trade unions. ${ }^{42}$ It was also amongst the most militant.

Mining was a notoriously dangerous industry to work in, with astronomically high injury and death rates in the Victorian period. Of all working-class communities, mining communities had the largest proportion of disabled men, from both injuries sustained in "accidents" underground and from chronic disease, most seriously from respiratory impairment caused from inhaling dust on the job. Here disability was normalised. ${ }^{43}$ In the interwar years, around half of all workmen's compensation claims in the UK were made by coal miners.

Not surprisingly miners' unions campaigned long and hard on occupational health and safety issues. ${ }^{44}$ According to the Webbs, the miners' unions played a key role in campaigning for improved mines legislation from the 1860 s to $1910 .{ }^{45}$ Three of the seven founding objectives of the MFGB (the "Fed") laid down in 1889 concerned safety. A key focus was to improve health and safety through campaigning to extend and improve the mines and workmen's compensation statutes. ${ }^{46}$ The power of the "Fed," recognised by the owners for national collective bargaining, provided the impetus to make real changes. For example, three MFGB officials were appointed to the nine-person strong Royal Commission on Mines which sat from 1906-11. The 1911 Mines Act provided the most extensive matrix of support for British miners to date, including the right to appoint workmen's inspectors (effectively trade union health and safety officers) to inspect sites where accidents had occurred. By 1914 a minimum wage (by coalfield area agreement) and an eight hour day were achieved (uniquely amongst British workers at this time). Both were important in maintaining a healthier work-life balance, with the minimum wage acting to take some pressure off miners to take risks to make a decent income. Concurrently, the miners' unions and their political representatives in parliament spearheaded the campaign to get decent levels of financial compensation for miners and their families affected by injuries, deaths and disease in the pits. Key victories here were the passage of the Employers' Liability Act in 1880 (after over 15 years of pressure from the miners unions and the TUC) and the first Workmen's Compensation Act in 1897, which finally gave workers and widows some "no fault" financial compensation for death and disability in pit accidents. ${ }^{47}$

It was to be some time, however, before miners' industrial diseases were to be added to the list of diseases that could attract compensation under the Act. Crucially silicosis was not included on the list until 1918. Coal workers' pneumoconiosis was not officially recognised until 1943. This, too, came after long and persistent campaigning by the miners' trade unions, led by the South Wales Miners' Federation

40. Peter Bartrip, “Petticoat Pestering': The Women's Trade Union League and Lead Poisoning in the Staffordshire Potteries, 1890-1914," Historical Studies in Industrial Relations 2 (September 1996): 3-26.

41. Bowden and Tweedale, "Mondays without Dread."

42. Robert Page Arnot, The Miners: A History of the Miners' Federation of Great Britain from 1910 Onwards (London: George Allen and Unwin, 1953), 545.

43. David M. Turner and Daniel Blackie, Disability in the Industrial Revolution: Physical Impairment in British Coal Mining 1780-1880 (Manchester: Manchester University Press, 2019).

44. McIvor and Johnston, Miners' Lung, 185-233; Dave Lyddon, "Trade Unions and the History of Health and Safety in Britain," Historical Studies in Industrial Relations 35 (2014): 157-79. Lyddon's important paper focuses on coal mining in an extended review of McIvor and Johnston, Miners' Lung and Catherine Mills, Regulating Health and Safety in the British Mining Industries, 1800-1914 (Farnham: Ashgate, 2010).

45. Webb and Webb, Industrial Democracy, 364.

46. Lyddon, "Trade Unions," 161.

47. See Ibid., 157-79 for a detailed discussion of these developments. 
(SWMF). The SWMF played a key role between the wars in challenging the prevailing medical orthodoxy. This was fixated on silica as the injurious agent and even held that coal dust was benign, indeed protected miners' lungs against contracting tuberculosis. One of the SWMF's tactics was to initiate medical surveys amongst its members. Another was to support wider initiatives. In the 1940s and 1950s, this included community-wide pneumoconiosis X-ray campaigns and pit-level monitoring research. The Pneumoconiosis Fieldwork Research campaigns in 25 selected pits ran over more than two decades. ${ }^{48}$ At the national level union policy was enshrined in the Miner's Charter drawn up by the newly created National Union of Mineworkers in December 1945. Four of the 12 clauses of the Charter dealt with occupational safety and health issues, with a renewed emphasis on prevention, medical exams, health promotion and acute occupational disease. ${ }^{49}$

While the unions were joined by radical politicians, philanthropists, progressive doctors and Members of Parliament, including the miner MPs like Alex MacDonald, Thomas Burt and Keir Hardie, the miners themselves and their unions were pivotal interlocutors in protecting miners' health. As David Lyddon has persuasively argued, the unions were "the single most important force for regulation and improvement." ${ }^{50}$ Quinlan, Bohle and Lamm endorse this view of the vanguard role of mining in many countries which was shared by the waterfront unions. ${ }^{51}$ Where mining unions were less effective - for example in the USA - coal workers' pneumoconiosis was regulated much later (1969) than it was in Britain (1943). ${ }^{52}$

In the nineteenth century, however, most unions remained precarious in the face of much entrenched employer opposition. Hardly surprisingly job security and wages were perceived by workers in all but the most dangerous trades to be the crucial elements in maintaining health and well-being for themselves and their families. Unions had to appeal to what their members wanted. Workers were long acculturated into work regimes that impacted negatively on their bodies, in which high accident, injury and disability rates prevailed. Furthermore in an era when ill-health and low life expectancy was the norm from other rampant infectious diseases (such as tuberculosis), chronic ill-health caused by workacquired disease (such as pneumoconiosis) was a distant concern, a long-term risk. The relative invisibility of chronic occupational health issues delayed attention from unions fixated on the carnage of occupational injuries and mortality. To some extent risks at work were compensated with a higher wage premium, the "danger money." In this context - perhaps right up to the creation of a comprehensive Welfare State in the $1940 \mathrm{~s}$ - it was quite rational for trade unions to prioritise wages and financial compensation over campaigns on occupational health and safety. Mobilising support for chronic health issues that affected workers in varied ways to different degrees, was intrinsically difficult as opposed to campaigns against wage cuts or for wage rises which affected most if not all workers.

Over time, the union movement came to campaign persistently on OHS at work in tandem with other issues, including wages, shifting their focus to embrace chronic disease as well as acute safety issues. Trade unions aimed to protect and advance the interests of workers and OHS was central to this in union thinking and action at a number of levels, especially where unions had the numerical strength and capacity to take the issues on board. With perhaps a little exaggeration, the Webbs asserted in 1894: "In the trade union world of today, there is no subject on which workmen of all shades of opinion, and all varieties of occupation, are so unanimous, and so ready to take combined action, as the prevention of accidents and the provision of healthy workplaces."53 Similarly Quinlan, Bohle and Lamm noted that in Australia, for worker organisations formed between 1795 and 1900, "health and safety ranked as the fourth most frequently cited union objective (wages and hours ranked top) and that working conditions (including health and safety) was the fourth most commonly cited issue involved in strikes and disputes." 54

48. For a fuller discussion of the trade union campaigns on dust disease in coal mining, see McIvor and Johnston, Miners' Lung, 185-236.

49. Ibid., 200-201.

50. Lyddon, "Trade Unions," 179.

51. Quinlan, Bohle and Lamm, Managing Occupational Health and Safety, 495.

52. McIvor and Johnston, Miners' Lung, 230-33.

53. Webb and Webb, Industrial Democracy, 357. Emphasis added.

54. Quinlan, Bohle and Lamm, Managing Occupational Health and Safety, 489. 
A wide body of literature documents trade union challenges to prevailing discourses that blamed workers for the damage wrought to their health and shows union efforts to safeguard and promote the health and well-being of their members and other workers. OHS discourse was framed in the nineteenth century statutory regime of preventative legislation and later, importantly, of "no fault" workmen's compensation legislation from the 1890s. Strategically, trade union activity became focussed on the national level. With the formation of the TUC, in 1867, campaigning and lobbying was to extend statutory protection and legal rights rather than take direct action in the form of strikes. Responsibilities expanded in the twentieth century. Activity on OHS had considerable success, for example, in achieving shorter working hours, progressively extending factory and mines Acts, in new regulations governing the "dangerous trades" and in the clear establishment of the right to workmen's compensation for "accidents" in 1897. From 1906, this extended to a widening range of occupational diseases. Health education and promotion, as Long has shown in a beautifully-crafted monograph, was also a key part of TUC policy between the two world wars. ${ }^{55}$ Gaps in legislative provision, neglect of women workers, or evasion of regulation continued. Still, unions had achieved much with a logical deployment of resources to improving working conditions and OHS standards across the board, for unionists and non-members alike. Other scholarship has challenged the notion that unions prioritised financial compensation over prevention. ${ }^{56}$ There was a clear preventative element to the pursuit of workmen's compensation, when hitting the employers in the pocket forced them (sometimes under pressure from their insurers) to correct dangerous working conditions.

Where mobilisation occurred against asbestos it began with strongly unionised clusters, such as the Glasgow laggers' (pipe coverers and insulation workers) branch of the Transport and General Workers' Union in the 1950s and 1960s, the London dockers in 1965 and building workers on wellunionised sites in the later 1960s and 1970s. ${ }^{57}$ Union responses to asbestos reflected different problems. Coal mining disasters were in the public eye in a way that asbestos was not (at least until the media exposes of the 1980s). It was easier to mobilise public support for effective statutory reform when acute injury and mortality was tangible and visible. Occupational disease was frequently invisible, slowly encroaching upon and damaging tissue, organs and bones by stealth. In contrast to coal mining, the asbestos issue was spread across a disparate group of industries - textiles, construction, shipbuilding, the docks - where unions were less entrenched or more divided making it harder to mobilise opposition. Added to this was a significant pro-asbestos lobby within some UK trade unions fearful of the impact a ban on asbestos would have on jobs, fears exacerbated by the deep recession from the late $1970 \mathrm{~s} .{ }^{58}$

The story of asbestos illustrates a wider point about the spectrum of responses and positions on OHS across a heterogeneous, voluntary union movement where tensions existed between jobs, wages and health. Many workmen feared medical inspection and exposure of problems in their workplaces that might provoke regulation that could jeopardise jobs. Sensitivities here could filter through to influence trade union policies. Identifiably macho work cultures in industries like construction, steel, mining and shipbuilding constituted a drag anchor, despite union efforts on the job to change attitudes. Moreover, unions in sectors of the economy where dangers and chronic ill-health were evidently more of a problem (like coal mining) were perhaps inevitably going to be more pro-active than where workplaces were seemingly more benign - such as offices and shops or working on the land, where risks to health were significant, but far less visible. Agriculture would be a case in point where trade unionism failed to gain a foothold and OHS hardly featured in union campaigns. Before World War II, union membership in agriculture and forestry in the UK hovered persistently below ten per cent and barely touched a quarter of the workforce even in the post-war heyday of trade unionism. ${ }^{59}$ This left a legacy. It is perhaps no

55. Vicky Long, The Rise and Fall of the Healthy Factory (Basingstoke: Macmillan, 2011), 85-129.

56. Mark Bufton and Joe Melling, "Coming Up for Air: Experts, Employers and Workers in Campaigns to Compensate Silicosis Sufferers in Britain, 1918-1939," Social History of Medicine 18 (2005): 85.

57. Dalton, Asbestos Killer Dust, 98-101; Johnston and McIvor, Lethal Work, 158-72.

58. Helen Chappell, "Fighting Each Other over Asbestos," New Society, 29 September 1983, 471-73.

59. McIvor, A History of Work, 202. 
coincidence that in the early twenty-first century agriculture and forestry has risen to be one of the most hazardous of all sectors globally. ${ }^{60}$

Economic and political milieu affected the capacities of trade unions to mobilise on OHS. The 1930s were a period of retrenchment for the unions and deteriorating OHS standards in many of the failing heavy industries across the developed Western economies. The worst coal mining disaster between the wars in the UK at the Gresford Pit in North Wales in 1934 was attributed to managerial negligence, enabled to a degree by the erosion of a union presence in the district. Less than 30 per cent of the 266 men killed were paid up union members. ${ }^{61}$ The outbreak of war in 1939 empowered labour. Economic and political necessity provided an environment in which trade union initiatives on OHS flourished. ${ }^{62} \mathrm{We}$ see this, for example, in the proliferation of joint production committees on which union officials made the case for OHS as a wartime "efficiency" measure. During the war some unions, such as the Foundry Workers' Union, initiated important campaigns to tackle long-standing issues around health and safety, including the scourge of silicosis in the industry. ${ }^{63}$

After the war, trade unions enjoyed a "Golden Age" as part of the fabric of British society. From the 1940s to the 1970s they came to exert much more influence over OHS. The same can be said for Australia, New Zealand and most countries across Western Europe, especially Scandinavia where unions perhaps exerted most influence shaping the "social protection regime." ${ }^{64}$ In the UK, union membership and density rose from a nadir of less than five million members and a quarter of the workforce in 1930 to a peak of 13 million members and over 50 per cent in the late 1970s. Campaigning for statutory reform continued, and was a key element of the post-war Labour government's Welfare State in the workplace. Workmen's compensation law was overhauled and replaced with the more generous Industrial Injuries Act in 1947. There followed the recognition of tuberculosis (TB) as an occupational disease in 1951, after a long campaign spearheaded by the TUC's Medical Adviser, and in 1961 the passage of a new more comprehensive Factories Act. ${ }^{65}$ The scheduling of TB was significant because it signalled a campaign that was directed primarily at the female workforce, nurses and health workers. In addition there was a vigorous campaign by the union movement - ultimately unsuccessful - to integrate an occupational health service within the fledgling National Health Service (NHS) ${ }^{66}$

The TUC also campaigned to extend union safety representatives and committees across all sectors of industry and widen health and safety legislation to cover all workers. The nationalisation of a swathe of heavy industries - a long-term aim of the trade union movement spearheaded by the miners resulted directly in improved OHS standards, most evidently, perhaps, in coal mining, steel and transport. Union action thus contributed to saving many lives. Occupational "accident" deaths, as a proportion of workers employed, dropped markedly from the 1940s to the 1970s ${ }^{67}$

As important, perhaps, was the proliferation of shop stewards in the 1950s-70s. As Quinlan, Bohle and Lamm argued, OHS was increasingly being bargained over, with union intervention at a number of levels including crucially in the workplace, at the point of production. ${ }^{6}{ }^{8}$ In the UK numbers of shop stewards rose from 90,000 in 1961 to 250,000 by $1980 .{ }^{69}$ These union activists provided another layer of protection. They came to play a key role in OHS in the workplace, identifying issues and representing workers, acting as unofficial "welfare" consultants, challenging managerial power and

60. ILO, Safety and Health in Agriculture (Geneva: ILO, 2011), 5.

61. Robert Page Arnot, The Miners in Crisis and War (London: George Allen and Unwin, 1961), 139.

62. Juliette Pattinson, Arthur McIvor and Linsey Robb, Men in Reserve: British Civilian Masculinities in the Second World War (Manchester: Manchester University Press, 2017), 168-80, 191-231.

63. Hubert J. Fyrth and Henry Collins, The Foundry Workers (Manchester: Amalgamated Union of Foundry Workers, 1959), 223-24; 292-98.

64. Quinlan, Bohle and Lamm, Managing Occupational Health and Safety, 492.

65. See Arthur McIvor, "Germs at Work: Establishing Tuberculosis as an Occupational Disease in Britain, c19001951," Social History of Medicine 25, no. 4 (2012): 812-29.

66. Long, The Rise and Fall of the Healthy Factory, 156-86.

67. "Historical Picture Statistics in Great Britain, 2019: Trends in Work-Related Ill Health and Workplace Injury," Health and Safety Executive, accessed July 2020, www.hse.gov.uk/statistics/history.

68. Quinlan, Bohle and Lamm, Managing Occupational Health and Safety, 489-91.

69. Alan Booth and Joseph Melling, "Workplace Cultures and Business Performance," in Managing the Modern Workplace, ed. Joseph Melling and Alan Booth (Aldershot: Ashgate, 2008), 9. 
entrenched macho work-health cultures, thus raising OHS standards across the board. One vulnerable immigrant worker when asked in 1980 why he had joined a union put it this way: "What the management would like to do to the workers is prevented by the unions, so we are protected." 70 A former company manager recalled in an interview in 2005:

Particularly from 1945 onwards, if an operative found himself exposed to something that he considered dangerous he would take it up with his union shop steward who would then take it up with the management who had to have a proper look at it. I think the unions were very active and effective in promoting health and safety. ${ }^{71}$

These union initiatives culminated in the wholesale overhaul of the OHS regulatory system with the Health and Safety at Work Act of 1974 bringing an additional eight million workers into the orbit of regulation, including in agriculture, schools and hospitals. Related legislation followed in 1977 when the Safety Representatives and Safety Committee Regulations forced employers to establish safety committees and safety representatives with full powers to inspect. At the centre of this was the idea that employers had a "duty of care" and needed to initiate risk assessments to determine if changes in work affected OHS. The new legislation in turn ushered in an era of unprecedented training of trade union health and safety representatives, cascading down knowledge and expertise to the shop floor and assisting further positive changes in OHS in industry. 80,000 people were trained in the ten day TUC health and safety training courses over 1974-82. Lyddon has argued that "this mass provision of training, more than anything, was probably responsible for the distinct culture shift on health and safety, within many workplaces, that occurred from the late 1970s." ${ }^{72}$ As Quinlan, Bohle and Lamm have shown, a surge in union involvement in OHS from the 1970s is evident across most developed countries. ${ }^{73}$

The new UK legislation had its flaws, and blind spots remained. Quinlan, Bohle and Lamm identify one of the core union methods on OHS as being to protect OHS activists from victimisation. ${ }^{74}$ In some sectors in the UK, notably the building industry, union health and safety officers could find themselves quietly sacked, victimised, blacklisted and denied work in a scandalous misuse of power by the industry, supported by right-wing social movement organisations. ${ }^{75}$ The oil industry was omitted from the provisions of the Health and Safety at Work Act 1974 and a "gung-ho" anti-union productionist culture led directly to disaster in 1988 when 167 oil workers lost their lives in the Piper Alpha rig explosion. ${ }^{76}$ The oil union's subsequent prioritisation of OHS was clearly evident in the tragedy's aftermath, illustrating once again how a major disaster was necessary to prompt reform and effective regulation.

That the unions had a really positive effect on OHS standards in the UK was demonstrated in several research papers. Whilst the UK data remained challenging to interpret, some accounts suggested that in non-unionised workplaces workers were around 50 per cent more likely to be killed in a workplace accident as in a unionised workplace. ${ }^{77}$ Hazards magazine estimated that 2.5 million

70. Annie Phizacklea and Robert Miles, Labour and Racism (London: Routledge and Kegan Paul, 1980 ), $102-103$.

71. Interview by David Walker with Brian Watson, 8 October 2005, 022, SOHCA.

72. Dave Lyddon, Health and Safety, Britain at Work, London Metropolitan University, accessed July 2020, http://www.unionhistory.info/britainatwork/narrativedisplay.php?type=healthandsafety.

73. Quinlan, Bohle and Lamm, Managing Occupational Health and Safety, 485-500.

74. Ibid., 485 .

75. See the wonderful documentary, Solidarity, dir. Lucy Parker (London: City Projects, 2019), accessed July 2020 , http://www.solidarityfilm.com/; Chappell, "Fighting Each Other," 472-73; House of Commons Scottish Affairs Committee, Blacklisting in Employment: Final Report Seventh Report of Session 2014-15, HC 272, 18 March 2015 (London: The Stationery Office), accessed July 2020, https://www.parliament.uk/blacklisting-inemployment.

76. Mathias Beck, John Foster and Charles Woolfson, Paying for the Piper (London: Routledge, 1996).

77. Barry Reilly, Pierella Paci and Peter Holl, "Unions, Safety Committees and Workplace Injuries," British Journal of Industrial Relations 33, no. 2 (1995): 275-88; Theo Nichols, David Walters and Ali Tasiran, "Trade Unions, Institutional Mediation and Industrial Safety," Journal of Industrial Relations 49, no. 2 (April 2007): 211-25. See also Trades Union Congress, The Union Effect: How Unions Make a Difference on Health and Safety (London: TUC, 2015), accessed July 2020, https://www.tuc.org.uk/research-analysis/reports/union-effect. 
serious injuries had been saved over the first 20 years of the workplace safety officers appointed under the 1977 legislation, claiming "Workplaces with a full union safety structure are twice as safe as those without." 78 Another study of 31 industrialised countries concluded that "union density is the most important external determinant of workplace psychosocial safety climate, health and GDP."79 The latest ILO data also supports this conclusion. Globally, where there are strong independent trade unions, fatality rates on the job tend to be considerably lower than where union densities are low or no independent trade union exists (as, for example, in China). The USA, for example, with only ten per cent of its workers in trade unions, had an occupational accident fatality rate (per 100,000 workers) in 2018 almost three times higher than the Scandinavian countries, where unionisation rates average over 60 per cent. ${ }^{80}$ There is also a strong correlation between unionisation rates and countries ratifying ILO conventions on health and safety. ${ }^{81}$ Trade union resources have clearly made a real difference, as the ILO argued in 2002:

Since their very inception, trade unions have seen the improvement of working conditions as one of their top priorities. And indeed, progress in that field, including a clear decrease in work-related accidents in the industrialized world, the improvement of work methods and recognition of the human factor in industries over the last century, owes a lot to efforts by organized labour. ${ }^{82}$

Trade union activities on occupational health also contributed to wider public health campaigns and working-class environmentalism, a fact often overlooked in the OHS literature but argued elsewhere in relation to tuberculosis. ${ }^{83}$ Quinlan, Bohle and Lamm have made the point that unions were frequently involved in alliances and collaborations in public health and community-based campaigns. ${ }^{84}$ As scholars have shown for the USA, and Karen Bell for the UK, there was a cross-fertilisation between occupational and environmental health, that was evident, for example, in campaigning on issues like pneumoconiosis, byssinosis, lead and asbestos, and recent union promotion of sustainable development. ${ }^{85}$ Again, we need more research to deepen our understanding of the role of the trade unions in this, and to determine their relationships with the wider public health, community and environmental movements such as the pioneering UK Occupational and Environmental Diseases Association, established in 1979.

\section{Challenging Times: Deindustrialisation, Neo-Liberalism and OHS}

As Quinlan, Bohle and Lamm have argued, the trade unions upped their game from the mid/late 1970s becoming more proactive on OHS. The growing interest in OHS has not been confined to unions in Australia and New Zealand: "Comparable or even earlier trends can be identified in the US, Britain, Finland, Norway, Denmark, Sweden and a number of other industrialised countries." 86 The unions also

78. Hazards 64, (October-December 1998). See also Rory O’Neill, "When It Comes to Health and Safety Your Life Should Be in Union Hands," in ILO, Health and Safety at Work: A Trade Union Priority, Labour Education Series, 2002/1, no. 126, (Geneva: ILO, 2002),13-18.

79. Maureen Dollard and Daniel Neser, "Worker Health is Good for the Economy," Social Science and Medicine 92 (September 2013): 114-23. See also ILO, Health and Safety at Work, and Quinlan, Boyle and Lamm, Managing Occupational Health and Safety, 488-89.

80. Compare: "Statistics on Union Membership," ILOSTAT, International Labour Organisation, accessed July 2020 , https://ilostat.ilo.org/topics/union-membership/; "Statistics on Safety and Health at Work," (Fatal Occupational Injuries per 100,000 Workers by Economic Activity: Annual), ILOSTAT, International Labour Organisation, accessed July 2020, https://ilostat.ilo.org/topics/safety-and-health-at-work/.

81. ILO, Health and Safety at Work, 5.

82. Ibid., v.

83. McIvor, "Germs at Work."

84. Quinlan, Bohle and Lamm, Managing Occupational Health and Safety, 487.

85. Chris Sellers, Hazards of the Job: From Industrial Science to Environmental Health Science (Chapel Hill: University of North Carolina Press, 1997); David Rosner and Gerald Markowitz, Deadly Dust (Princeton: Princeton University Press, 1994); Gerald Markowitz and David Rosner, Lead Wars (Berkeley: University of California Press, 2013); Karen Bell, Working Class Environmentalism (Basingstoke: Palgrave Macmillan, 2020). 
became more sensitive to OHS issues affecting migrant, black and minority ethnic, and female workers, partly as a result of pressure from the feminist, equal/civil rights and community movements and partly from the changing gender demography of union membership. By 2019, women constituted 57 per cent and men 43 per cent of total union membership in the UK. ${ }^{87}$ Deindustrialisation sucked workers out of more dangerous industrial jobs - like coal mining, steel, shipbuilding, the docks - into more benign white-collar service occupations, mainly working in offices. Consequently, workplace fatalities and selfreported injuries continued to fall, the former by 84 per cent from 1974 to $2018{ }^{88}$ At 0.8 deaths per 100,000 workers, the UK's occupational fatality rate was comparable to Scandinavia and amongst the lowest in the world in 2018 - half that of Japan and Australia; one quarter that of the USA. ${ }^{89}$ The continuation of legislative controls under the Health and Safety at Work Act and the importance of European Union OHS directives were stabilising factors in the UK.

Weighed against this is the persuasive argument that occupational "accident" mortality data is relatively meaningless in a post-industrial economy where health and well-being are more indicative measures. There is considerable evidence that deindustrialisation, modern work management regimes and precarious work patterns have made the workplace an increasingly unhealthy environment and that the corrosion of a trade union presence in the workplace has contributed to a mental health crisis at work. This manifested itself in the stress epidemic that has swept through the modern workplace. ${ }^{90}$ In a TUC survey of union health and safety representatives in 2016, one third identified stress as the top hazard in their workplace, and 70 per cent saw it as one of the top five hazards. ${ }^{91}$

Trade union decline and retrenchment has characterised recent decades. From over 50 per cent in 1979, trade union density (the proportion of total workers who were union members) in the UK in 2019 stood at 23.5 per cent (6.44 million) ${ }^{92}$ Australia witnessed a sharper decline from 50 per cent to 13 per cent (2013). ${ }^{93}$ This collapse in union membership has occurred across many developed economies where deindustrialisation has been deepening and neo-liberal politics have been embraced with an agenda of deregulation, self-regulation, voluntarism and anti-trade union legislation. In the UK, this attack on the trade unions was particularly ferocious in the Thatcher era, with a more rapid, accelerated and sustained process of deindustrialisation in the 1980s and 1990s than most European countries. The deep and enduring economic recession saw rising levels of unemployment, peaking at ten to 12 per cent for several years from 1980-87 and again over 1992-94. Between 1979 and 2010, the UK lost 4.3 million manufacturing jobs.

The proliferation of deindustrialisation studies since the 1980s have rightly identified the ruination of working-class communities. Steady, well-unionised, industrial jobs disappeared as mines, factories, docks and yards closed. ${ }^{94}$ Unemployment had a known adverse impact on health and wellbeing, physical and mental. Where workers transitioned into different jobs, these were invariably less secure, less paid, less well unionised and less regulated. In the early-1990s, just one in four of those who had been miners a decade before had a full-time job. ${ }^{95}$ For many young people, especially those without a privileged university education, it was poorer jobs that were available compared to the generation

87. Department for Business, Energy and Industrial Strategy (DBEIS), "Trade Union Membership, UK 1995-2019: Statistical Bulletin,” 27 May 2020, National Statistics, accessed July 2020,

https://assets.publishing.service.gov.uk/government/uploads/system/uploads/attachment_data/file/887740/Tradeunion-membership-2019-statistical-bulletin.pdf.

88. "Historical Picture Statistics in Great Britain, 2019."

89. "Statistics on Safety and Health at Work," (Fatal Occupational Injuries per 100,000 Workers by Economic Activity: Annual).

90. Health and Safety Executive (HSE), The Stress and Health at Work Study (London: HMSO, 1998);

91. See "Rep Guidance: Stress," Trades Union Congress, accessed July 2020, https://www.tuc.org.uk/unionreps/health-safety-and-well-being/stress.

92. DBEIS, "Trade Union Membership, UK 1995-2019.”

93. “Tade Union,” OECD.Stat, accessed July 2020, https://stats.oecd.org/Index.aspx?DataSetCode=TUD.

94. Amongst the most recent work has been Steven High, Lachlan MacKinnon and Andrew Perchard, eds, The Deindustrialized World (Vancouver: University of British Columbia Press, 2017).

95. Edward Fieldhouse and Emma Hollywood, "Life after Mining: Hidden Unemployment and Changing Patterns of Economic Activity amongst Miners in England and Wales, 1981-1991," Work, Employment and Society 13, no. 3 (1999): 487. 
before, on short-term casual contracts; as self-employment; or in non-unionised workplaces. "Flexibility" and polarisation in the labour market widened inequalities, and for those at the bottom, union protections were virtually non-existent.

Workers who remained employed in struggling, down-sizing industries felt the pressure. A number of empirical studies demonstrated deleterious impacts on psychological health and well-being as a consequence of deepening work stressors associated with longer work hours, managerial pressure, and lack of autonomy and control of work under changing production regimes, such as "lean production." 96 Tombs has shown how OHS standards in some sectors deteriorated sharply in the 1980s UK recession: between 1981 and 1985, fatal and major injury rates increased across British manufacturing by 31 per cent and in construction by a staggering 45 per cent. ${ }^{97}$ With regulatory degradation, workers' rights were eroding, including rights to compensation for injuries and disease. ${ }^{98}$ Workers themselves frequently expressed experiencing change as disconcerting and destabilising, of having a profound sense their skills were being undermined as control and autonomy on the job eroded. ${ }^{99}$ Unemployment and fear of job loss had a pervasive disciplining effect on workers and risks to health were increasingly tolerated in this context. ${ }^{100}$ As often was the case, poorly unionised migrant workers were the most vulnerable. One Chudar Singh Jandu - recalled that in the foundries in Coventry in the 1980s "The general working conditions were very bad - there was not much point complaining about health and safety. We were just happy to be here ... The wages were low, long hours, and dirty working conditions."101

With regard to the 1980s and 1990s, Wichert has argued, "[T]here is consistent, international evidence for the detrimental effects of the experience of both job insecurity and work intensification on psychological health and well-being." 102 A later report in 2012 by the Joseph Rowntree Foundation into conditions faced by migrant workers found a general climate of fear and powerlessness in the absence of trade unions and work conditions characterised by long hours (averaging 50 a week) with much "psychological harm" ensuing. ${ }^{103}$

This rise in workplace stressors was also evident in coal mining in the UK, as studies of pits have found. ${ }^{104}$ One ex-miner recalled the switch in his colliery, from conventional methods to "intense mechanisation" without proper training, noting "They did increase the production, but again that was at the expense of men's health ... we had a lot of men that were injured there." 105 The period after the defeat of the miner's strike in 1984-85 witnessed the emergence of a new pattern of industrial relations and work practices, with management (now British Coal) empowered and the National Union of Mineworkers neutralised. ${ }^{106}$ The employment of outside contractors increased, non-unionism grew significantly, the union was undermined by internal divisions and the health and safety functions of pit

96. Peter L. Schnall, Marnie Dobson, and Ellen Tosskam, eds, Unhealthy Work: Causes, Consequences, Cures (New York: Baywood, 2009). Paul Bellaby, Sick from Work: The Body in Employment (Aldershot: Ashgate, 1999), 213 found a clear link between rising unemployment and "stress amongst those in employment."

97. Steve Tombs, "Industrial Injuries in British Manufacturing," Sociological Review 38, no. 2 (1990): 324-43. See also Steve Tombs and Dave Whyte, Safety Crimes (Devon: Willan Publishing, 2007).

98. Andrew M. Robinson and Clive Smallman, "The Contemporary British Workplace: A Safer and Healthier Place," Work, Employment and Society 20 (2006): 87-107.

99. See, for example, Andrew Brunton, interviewed by Ian MacDougall, 17 January 1997, SOHCA.

100. See Johnston and McIvor, Lethal Work, 106-109; McIvor and Johnston, Miners' Lung, 237-72.

101. Cited in Herbert Gallery, Coming to Coventry (Coventry: Coventry Teaching PCT, 2006), 48.

102. Ines Wichert, "Job Insecurity and Work Intensification: The Effects on Health and Well-Being," in Job Insecurity and Work Intensification, ed. Brendan Burchill, David Ladipo and Frank Wilkinson (London: Routledge, 2002), 110. Emphasis added.

103. Cited in Andrew Watterson, Rory O’Neill, Tommy Gorman and Jim MCourt, “Occupational Health and Safety in Scotland," March 2014, 10-11, Jimmy Reid Foundation, accessed July 2020, http://reidfoundation.org/wpcontent/uploads/2014/03/HealthandSafety-1.pdf.

104. David Waddington, Charles Critcher, Bella Dicks, and David Parry, Out of the Ashes: The Social Impact of Industrial Contraction and Regeneration on Britain's Mining Communities (London: The Stationary Office, 2001), 52.

105. Mills, interview.

106. Waddington et al., Out of the Ashes, 130-31; Emma Wallis, Industrial Relations in the Privatised Coal Industry (Aldershot: Ashgate, 2000), 240-41. 
deputies were eroded. ${ }^{107}$ This was taken to higher levels with privatisation and the fragmentation of ownership from 1994, with the growth of local bargaining and some coal companies refusing trade union recognition entirely. ${ }^{108}$ The traditional protective role of the miners' unions atrophied in this environment where there were rising stress levels and real disincentives to report injuries accurately. Concurrently, the true level of industrial disease remained obscured by the haemorrhage of workers from the industry. Occupational health and safety standards were compromised at many pits as a result. ${ }^{109}$ Significantly, pneumoconiosis and chronic obstructive pulmonary disease cases rose from the 1990s. ${ }^{110}$ Heightened respiratory disability was not just happening in the UK mines but elsewhere, including the USA where profit-maximising private coal owners, the disempowerment of labour and collapse of a trade union culture were implicated in deteriorating occupational health standards. ${ }^{111}$

Across key sectors of the economy in developed countries including the UK modern working conditions precipitated an epidemic of stress, overwork and RSIs. The rate of reported stress at work in the UK doubled between 1990 and 1999, affecting one in five workers and particularly prevalent amongst nurses, teachers and managers. ${ }^{112}$ By the 2010s work-related stress, anxiety and depression accounted for some 12-13 million working days lost annually in the UK economy - over half of the total - with professionals having three times the rate of such illness compared to manual workers. ${ }^{113}$ Stress broke the patterns of other occupational health epidemics being associated as much with women as men, and managers as other workers. Stress was associated with depression, anxiety attacks and other forms of mental illness, heightened risk of coronary heart disease, stomach ulcers and some cancers. Stress was also a contributory factor in unhealthy behaviour such as cigarette, alcohol and substance abuse. ${ }^{114}$ Precarious work in the modern economy has been unequivocally associated with psychological illhealth. ${ }^{115}$

These threats and changes prompted growing interest and intervention by the trade unions in OHS. The TUC was instrumental in exposing the levels of workplace stress and some unions - including the Universities and Colleges Union (UCU) and UNISON the public services union - organised work stress audits and fought for compensation from employers deemed to be responsible for psychological ill-health. However, with trade unions diminished and non-existent in many modern workplaces, there were limits to what could be achieved. Call centres - almost completely non-unionised - are a case in point. ${ }^{116}$ With declining trade union support, backing for families experiencing bereavement and cases for compensation from employers for negligence regarding their duty of care in health and safety fell sharply - dropping by over 60 per cent between 2000 and 2012. ${ }^{117}$ Prevention was also undermined by a deregulatory agenda and public sector spending cuts that saw personnel at the Health and Safety Executive (HSE) fall by 35 per cent from 4,545 in 1994 to 2,889 in 2012, with the number of occupational health inspectors falling even faster from 60 to just eighteen. ${ }^{118}$ HSE inspections were drastically cut and unannounced inspections virtually stopped. The cuts to HSE funding continued through the 2010s until

107. Wallis, Industrial Relations, 169.

108. Ibid., 239.

109. Ibid., 124-25, 169-70, 196.

110. McIvor and Johnston, Miners' Lung, 138-40.

111. Alessandro Portelli, They Say in Harlan County (New York: Oxford University Press, 2011), 151-56.

112. HSE, Stress and Health at Work Study; HSE, The Scale of Occupational Stress (London: HMSO, 2000); Carol Wolkowitz, Bodies at Work (London: Sage, 2006), 115.

113. HSE, Work-Related Stress, Anxiety or Depression Statistics in Great Britain, 2019, Annual Statistics, 30 October 2019, accessed July 2020, https://www.hse.gov.uk/statistics/causdis/stress.pdf.

114. David Wainwright and Michael Calnan, Work Stress: The Making of a Modern Epidemic (Buckingham: Open University Press, 2002), 3-4; Alan Dalton, Safety, Health and Environmental Hazards at the Workplace (London: Cassell, 1998), 136-37.

115. Joan Benach, Alejandra Vives, Marcelo Amable, Christophe Vanroelen, Gemma Tarafa, and Carles Muntaner, "Precarious Employment: Understanding an Emerging Social Determinant of Health," Annual Review of Public Health 35, no. 1 (March 2014): 229-53.

116. Phil Taylor, Chris Baldry, Peter Bain, and Vaughan Ellis, “'A Unique Working Environment': Health, Sickness and Absence Management in UK Call Centres," Work, Employment \& Society 17, no. 3 (September 2003): 435 58.

117. Watterson et al., "Occupational Health and Safety in Scotland," 8.

118. Ibid., 9, 12. 
finally being reversed in May 2020 as a consequence of the COVID-19 crisis. Whilst interest in OHS by the unions has clearly increased since the 1970s, and OHS has become a mobilising issue across many developed countries, the protective trade union-state matrix that had served workers well over the postwar decades has been fundamentally undermined in the recent past.

Globalisation contributed to this atrophy. Corporate disinvestment and shifting of production to low and middle income countries, where unions and social protection regulatory regimes were weak or non-existent, in turn, further undermined unions and their capacity to maintain OHS standards in deindustrialising modern economies like the UK. Asbestos provides a classic example of the shifting of toxic health risks from the older Western economies to low income industrialising countries, such as India and Bangladesh. ${ }^{119}$ This has all manifested in the UK and other developed high income countries in a workplace characterised by trade union marginalisation, a long-working hours culture, precarity, widening inequalities and an intensification of labour and excessive workloads that has corroded a healthy work-life balance for many. ${ }^{120}$

\section{Conclusion}

Trade unions were a product of their times - inclusive, sectional and capable of absorbing prevailing attitudes as well as radically challenging the status quo as transformative agents. The evidence suggests a more positive evaluation of their role on OHS is warranted. There were synergistic links between compensation and prevention in trade union policy in Britain. ${ }^{121}$ A range of positions existed within a heterogeneous trade union movement and union action ebbed and flowed, influenced by fluctuating labour markets and political context. Considered in international perspective and against the typology of union functions on OHS developed by Quinlan, Bohle and Lamm, the historical record of UK trade unions is a positive and proactive one, at many levels - national, sectoral and in the workplace. The UK sits somewhere between the Nordic countries and the significantly less well unionised southern European countries (such as Spain and Italy) and the USA.

The evidence strongly supports the view then that the trade unions in Britain, as elsewhere, have been pivotal sentinels playing a key role in protecting workers, developing and shaping the OHS discourse and improving OHS standards. They provided mutual insurance, bargained collectively with employers on OHS and advocated for effective social protective legislation, educated members on public and occupational health, and supported and extended workers' claims for financial compensation. The unions also played an important role in shifting the OHS discourse from victim-blaming that placed primary culpability upon the behaviour of the individual worker, to identification of structural factors around power, control, competition, profit and new managerial production regimes. The interests of trade unions on OHS progressively deepened with the 1970s marking a watershed in trade union mobilising on OHS issues. Initially narrowly focused on the interests of male workers and on safety (acute issues), the movement morphed into a more inclusive strategy in the later twentieth century incorporating female workers and recognising the "dual burden" of unpaid and paid work so central to the OHS experience of women. Here we see the unions shifting from their earlier historic function as agents representing vested and sectional interests to embracing a broader function as a transformative social movement. In this movement, workers' bodies became part of the struggle for social justice. The unions transitioned towards the modern discourse of shared responsibility and the employers having a "duty of care." Gains made in the past were and remain fragile, however, and have been widely undermined by the collapse in

119. Joseph LaDou, Barry Castleman Arthur Frank, Michael Gochfeld, Morris Greenberg, James Huff and Tushar Kant Joshi et al., "The Case for a Global Ban on Asbestos," Environmental Health Perspectives 118, no. 7 (2010): 897-901; Jock McCulloch, “Asbestos," in The Praeger Handbook of Environmental Health, Volume 2: Agents of Disease, ed. Robert H. Friis, (Santa Barbara, CA: Praeger, 2012), 193-206.

120. Michael Quinlan, Claire Mayhew, and Philip Bohle, "The Global Expansion of Precarious Employment, Work Disorganisation and Occupational Health: A Review Of Recent Research," International Journal of Health Services 31, no. 2 (2001): 335-414; Madeleine Bunting, Willing Slaves: How the Overwork Culture is Ruining Our Lives (London: Harper Collins, 2004).

121. Long, The Rise and Fall of the Healthy Factory, 128-29, 211-12. 
trade union membership and power across high-income economies since the 1970s, associated with deindustrialisation, neo-liberal politics and globalisation.

The subject demands more attention from researchers. We need to know more, for example, about the part played in the workplace by shop stewards and health and safety representatives and committees in changing work-health cultures, challenging the dual degenerative influences of a productionist and a macho work culture. Questions remain about how trade unions related to and developed alliances with other progressive forces, such as victims' pressure groups, community health and environmental campaigns and politicians (locally and nationally). More transnational comparative research, following the lead of Michael Quinlan and his colleagues, would also be extremely valuable. We also need to understand better how tensions played out between jobs and health, why and how a spectrum of positions existed across different trade unions - craft; industrial; service sector; professional and creative, breakaways - and between the rank and file and union leaderships. Working-class environmentalism expressed through the labour movement also merits more attention. Exploring such issues through a major oral history project with those who directly witnessed and experienced it, including union health and safety representatives from the shop floor to the union headquarters, would add invaluably to developing and deepening our understanding.

Trade unions in the UK, as elsewhere, have continued to act as a countervailing force muting the impact of vicious market forces and neo-liberal politics, individualism, deindustrialisation and globalisation in the recent past. And whilst uneven historically across the labour force, this has been a significant buffer in hard times. Unions made a big difference - and continue to do so. Clearly, unions have been resilient and are now much more engaged and invested in OHS than they once were. That said, their capacity to resist and to mediate wider forces has been critically disempowered now that less than a quarter of the UK workforce are union members, and collective bargaining has dissipated with a return to individual contracts as the norm. These are developments that have occurred to varying degrees across most high-income nations globally. Occupational health standards have deteriorated in the process. Physical acute injury and disability are still visible and continue to blight traditional working-class communities, as does chronic disease (including vulnerability to COVID-19) and deteriorating psychosocial health. The current mental health crisis at work, exacerbated by the COVID-19 crisis, demonstrates how trade union vigilance and action to protect workers is as relevant today as it was a century ago. A recent (2019) local survey at the University of Strathclyde, in Glasgow, Scotland found a long working hours culture (averaging 33 per cent over contract) and a rising incidence of mental health illness amongst academic staff (up by 41 per cent from the previous year). This matches industry-wide UCU surveys for the UK. At the extreme end, higher education workers have experienced breakdowns, burn-out and have been driven to suicide. ${ }^{122}$ Trade union vigilance is as vital as ever, if the impact of work-related injury is not to be just as devastating in the future as was the impact of industrialisation.

Arthur McIvor is Professor of Social History and Director of the Scottish Oral History Centre (SOHC), University of Strathclyde, Glasgow, Scotland which he co-founded in 1995. He was brought up in a working-class community in Coventry, England, and his father worked on the assembly line at the Standard Triumph/British Leyland car factory in Coventry most of his life. His research interests in the history of work, industrial relations and occupational health has resulted in several books, including Organised Capital (Cambridge University Press, 1996), and more recently Men in Reserve (Manchester University Press, 2017). He is currently investigating the impacts of deindustrialisation on health and well-being.

$<$ a.mcivor@strath.ac.uk>

122. See Catrin Haf Jones, "Lecturer's Widow Hits out at Cardiff University Workload," BBC News, 20 February 2019, accessed July 2020, https://www.bbc.co.uk/news/uk-wales-47296631. 